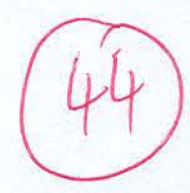

\section{THE ROLE OF CHINESE TRADERS ON THE GROWTH OF SONGKHLA, 1775-1912}

\section{Srisuporn Choungsakul}

\begin{abstract}
The article aims to study the growth of Songkhla1 between 1775-1912, marked by two periods of change within Songkhla proper. First, the $\mathrm{Na}$ Songkhla family played a major role in the growth of Songkhla between 17751896, and its development into an important port city on the gulf coast. Second, between 1896-1912, after the gradual decline of the role and influence of the Na Songkhla family, Chinese traders ascended and took its place, enabling Songkhla to sustain its economic development and dynamism as a port city .
\end{abstract}

The study reveals the significant role of families of Chinese traders in mobilizing the economic activities of Songkhla and enhancing its status as the leading city in the regional economy. Songkhla served not only as a center for the collection of goods from the hinterland, but also as a production site of export goods. The center of Songkhla's commerce was located on both sides of Nakhon Nai and Nakhon Noak roads which were

\footnotetext{
${ }^{1}$ Songkhla has two dimensions, first as the center of administration and second as the center of trade in the lower South of Thailand.
}

actually the Chinese quarter. Kinship was fostered among the Chinese in the community through inter-marriage. Multi-ethnic interactions between the Thais, the Chinese and the Muslims were carried out through trading activities in which the Chinese acted as intermediaries. During the same period, Songkhla town had become the center of government for the lower South: the commanding seat of Monthon Nakhon Si Thammarat and other official centers.

Thus the study shows the development and growth of Songkhla proper between 1896-1912, the crucial time in terms of government administration and the economy when the Chinese traders played the significant role in perpetuating the importance of Songkhla as a vital city in the economic sphere on the foundation laid down by the $\mathrm{Na}$ Songkhla family.

\section{Introduction}

Formerly known as Singora among Western people, Songkhla is a major natural port on the lower Gulf of Thailand and has long been an important center of trade on the eastern side of the isthmus. Present-day Songkhla is situated $947 \mathrm{kms}$. south of Bangkok along the railway line, $480 \mathrm{kms}$. from Kuala Lumpur, Malaysia, and $718 \mathrm{kms}$. from Singapore. Its eastern and northern areas comprise mostly coastal plains adjacent to the Gulf of Thailand and Nakhon Si Thammarat respectively. Those in the west and in the south comprise mountains alternating with plains and hills which climb up to Bantad and Sankarakiri Range, connecting to the areas in Patthalung, Setul, Yala, Pattani, and Kedah and Perlis in Malaysia. Due to its strategic position, Songkhla province has retained its importance as the center of trade, 
administration and economy in the lower South of Thailand

Since its foundation in 1605 at 'Hua Khaw Dang' by Dato Mogol, a Muslim Persian leader who accepted Thai suzerainty, the significant role of Songkhla as a major political and economic base in Southern Thailand has developed continuously. Economically, the Dato Mogol's liberal policy encouraged the growth of Songkhla as a major free port city in parallel to Nakhon Si Thammarat and Pattani. Evidence of Songkhla's prosperity in trade (which brought about wealth and security) was its proclamation of political independence from Ayutthaya, which lasted for 38 years (1642-1680). Several times punitive troops were sent before Ayutthaya could completely conquer Songkhla in 1680.

The battles devastated Hua Khaw Dang beyond recovery. After that, the town proper of Songkhla was moved to Laem Son area, under the administration first of Phatthalung and later of Nakhon Si Thammarat. As the new Thai rulers were not keen on trade, subsequently the role of Songkhla as a port city stopped for a certain period until a Chinese named Yiang Hao (the founder of the Na Songkhla family) was appointed by King Taksin to be Luang Inthakireesombat (Yiang), a bird-nest revenue farmer, with the title of Phra Songkhla. ${ }^{2}$ Subsequently, eight

${ }^{2}$ In 'Phongsawadan Muang Songkhla' written during the period of Chao PhrayaWichiankiree (Boonsung) in 1845, it is stated that when descendant ${ }^{3}$ of the family were entrusted by Bangkok to rule Songkhla in succession, covering a period of 126 years (1775-1901). Under the political and economic administration of the $\mathrm{Na}$ Songkhla family, Songkhla steadily grew until the town of Songkhla at Laem Son could no longer expand to accommodate further growth. In 1842, the town was again moved across the strait to the opposite tip at Bor Yang which has remained the site of Songkhla proper up to the present time (see map 1 showing the three sites of Songkhla).

As mentioned above, the development of Songkhla at the present time is associated with two groups of people: the Muslims and the Chinese who have contributed to the growth of Songkhla at different periods of time. This article aims to examine the role of the Chinese on the growth of Songkhla. It will discuss briefly the role of the Na Songkhla family on

Luang Inthakireesombat (Yiang) was appointed as the governor of Songkhla he was granted the title of Phra Songkhla (see Prachum Phongsawadan, Vol 30, p. 189). But in 'Phonsawadan Muang Songkhla' written by Phraya Wichiankiree (Chom) while he was Phraya Suntharanurak, the governor of Songkhla around 1870 , it is stated that the title granted to Luang Inthakireesombat (Yiang) was Luang Suwankirisombat (see Prachum Phongsawadan, Vol. 3, p. 39). The writer's opinion is that it is likely that Yiang was first granted the title of Luang Suwankireesombat as the governor of Songkhla, then was later promoted to the title of Phra Songkhla.

${ }^{3}$ 1. Phra Songkhla (Yiang) $1775-1784$ 2. Chao Phraya Intharakireesombat (Boonhui) 1784-1812 3. Phraya Wisethpakdi (Tienjong) 1812-1817 4. Phraya Wichiankiree (Tienseng ) 1817-1847 5. Chao Phraya Wichiankiree (Boonsung) 1847-1865 6. Chao Phraya Wichiankiree (Men) 1865-1884 7. Phraya Wichiankiree (Chum) 1884-1888 8. Phraya Wichiankiree (Chom) 1888-1901. 
the growth of Songkhla between 17751896 to form a basis for understanding the growth of Songkhla in the succeeding period. The emphasis will focus on the role of Chinese traders from 1896 when they influenced Songkhla's internal trading activities up to 1912 , when they began to change their economic ventures from trading to rubber-plantation capitalists and tin miners in line with the world economy.

\section{The Role of the Na Songkhla Family and the Growth of Songkhla, 1775-1896}

From the time the Chinese first played a role in the development of Songkhla in 1775 , the $\mathrm{Na}$ Songkhla family was the central actor up to 1896 when its influence gradually declined and other Chinese traders ascended and took its place, enabling Songkhla to continue its economic development.

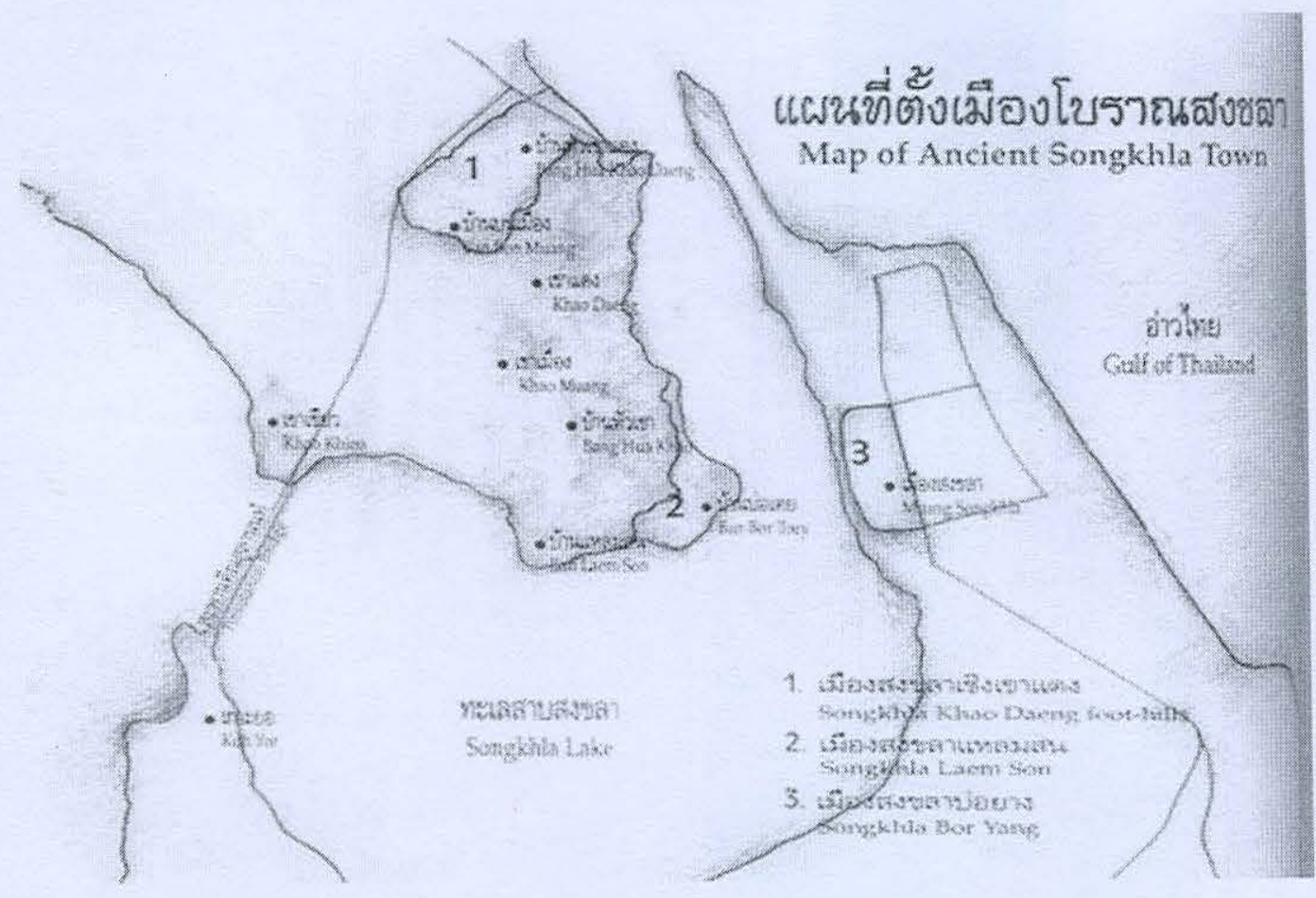

Map 1: The Three Sites of Songkhla Proper

Source: Office of Songkhla Province (n.p.,1990) 
Between 1775-1896 the Na Songkhla family was the most influential local power and dominated the internal economic activities of Songkhla. It was backed by the central power through the 'farming system,' which was the state apparatus in the local administration of the distant provinces. As characterized by the system, a pattern of 'semiindependent' economic practices of the $\mathrm{Na}$ Songkhla family was followed whereby the family was allowed to undertake economic activities within Songkhla city and those under its administrative authority. Nevertheless the $\mathrm{Na}$ Songkhla family was subjected to the political dominance of the central power and relied on the power of the latter to seek economic interest i.e. bird-nest farming, undertaking internal and external trade, tin-mining and economic exploitation both within Songkhla and other provinces under its administrative authority. These economic activities in time enhanced lower-level economic practices within Songkhla and surrounding areas. Through the political shrewdness and economic undertakings of the Na Songkhla family, Songkhla gradually developed into an important port city on the gulf coast.

Aside from its economic significance as a leading port city, Songkhla gained political importance in the South as it had been entrusted by the central power to govern the peripheral provinces in place of Nakhon $\mathrm{Si}$ Thammarat: to govern Pattani in 1791 (Prachum Phongsawadan, vol. 3, p. 53) and later in 1812 (Phongsiribanya, 1979:65-68) when Pattani was divided into seven principalities (Pattani, Saiburi, Yaring, Nongchik, Ra-ngae, Ramanh and Yala). Furthermore, Songkhla's territory expanded to cover Tambon Ban Phatong in 1811, Tambon Ban Karum, Tambon Ban Pha Koh in 1839 (Prachum Phongsawadan, vol. 3, p. 52-53, 74) and Tambon Ban Kamphaeng Phet in 1854 (Prachum Phongsawadan, vol. 30, p. 248) (Rataphum district at present). The annexation of these territories was economically vital to Songkhla as they are fertile lands which abound with natural resources and provide trading routes between Songkhla and Kedah.

The political and economic importance of Songkhla was further affirmed when the central power introduced the Thesaphiban system to govern local provinces, and Songkhla was chosen as the seat of the administrative command of Monthon Nakhon Si Thammarat in 1851. The underlying reason was the economic potential of Songkhla with increasing economic progress as perceived by the central power and the amicable relationship between its local elite, the Na Songkhla family, and the Siamese court. The Na Songkhla fanily was a new power group. They were Chinese immigrants who were more favourably responsive to the central power than the deeprooted indigenous elite of Nakhon $\mathrm{Si}$ Thammarat, the Na Nakhon. The latter fact was evident in the preparation for the reception of King Rama IV on his visit to Songkhla in 1859 which impressed the King so much that he was quoted as saying 'I have visited many towns but have never seen anyplace welcome me like this. The residence is strongly constructed and cost a lot of money. It has not been done in a bureaucratic fashion, but with a loving spirit for me [...]' (Prachum Phongsawadan, vol. 30, p. 276). This was in contrast to Nakon's preparation for the royal visit which showed 
many defects. Even the reception pavilion could not be finished in time so that Kalahom had to send his own men to help with the construction (Prachum Phongsawadan, vol. 30 , p. 266-67). In another event, during King Chulalongkorn's visit to Kedah on his passage to India, the governor of Nakhon Si Thammarat who was in charge of Kedah did not attend the reception, whereas the King was well received when he passed by Songkhla.

The events indicated the resistance of the local elite of Nakhon Si Thammarat to the central power. The setting up of the administrative command center at Nakhon $\mathrm{Si}$ Thammarat might have met with opposition from the local powers and created obstacles to the Thesaphiban reform which needed the cooperation of the governor. Therefore, the choice of Songkhla as the command center of Monthon Nakhon Si Thammarat was appropriate to the situation of the time.

The introduction of the Thesaphiban system to the administration of Songkhla affected changes in Songkhla politically and economically. Songkhla was drawn in to a closer relationship with the central power while its influence in the politics, administration and control of economic activities gradually declined. Under the new centralized, bureaucratic system, officials were sent directly from the central power to administer and control the implementation of state policy.

Nevertheless, the importance of Songkhla as a port city did not decline following the decline of the $\mathrm{Na}$ Songkhla family as other new Chinese families emerged to play a significant role in internal economic activities between 1896-1912, along the foundation laid by the Na Songkhla family.

\section{The Growth of Chinese Traders in Songkhla}

The majority of the Chinese immigrants in Songkhla came from Fukian, and were called 'Hokkian' in the local dialect. They were from the same region as that of the Na Songkhla founders. Generally, they migrated in groups and at sporadic times; ${ }^{4}$ they settled in a scattered pattern both inside the town proper and in the areas around, including the Songkhla lake and U-Taphaw basin. The Chinese migrations created economic movements both at the town, community and village levels. Trading and economic networks were built between the Chinese traders who came from the same regions or from the same clans. Subsequently, there several local Chinese lineages emerged as the local trader families in Songkhla Bor Yang i.e. the Ratanaprakarn family, the Ngoarangsi family, the Konan family, the Sakharin family, the Charoen family, the Adulyaphan family and the Hiranworachart family. Often the first generation ancestors landed at Laem Son before moving to Bor Yang. However, there were other families whose first generation ancestors migrated from China and did not originally settle in Songkhla, but in other cities before moving to Songkhla. These groups later became distinguished families in the economic realm of Songkhla. They include the Laekagul

${ }^{4}$ The Na Songkhla family supported Jeen Keng, their close friend from the same region in China, to be the governer of Jana (see Prachumphongsawadan, vol. 3, p. 53). 
family and the Chou family, which eventually divided into several family lines such as the Chou Ratarasarn, the Ratarasarn and the Prathanrasnikorn. These latter Chinese trader families all had their ancestors' tombs at Laem Son, the same place as those of the $\mathrm{Na}$ Songkhla family.

Initially, the business of the Chinese traders depended on the Na Songkhla family which held local power at the time. They cooperated with the Na Songkhla family by functioning as its auxiliaries in mobilizing the internal economic activities of Songkhla. Before 1896, the governing system used by the central state was the 'farming system' which rendered the Na Songkhlas the most powerful force in the internal administration and economy of Songkhla. In fact, the $\mathrm{Na}$ Songkhlas acted as the representatives of the central authority in supervising law and order, and collecting taxes, revenues and interest. This system gave the local governors and their provincial officials opportunities to abuse their position as evident in Prince Damrong Rajanubhab's explanation:

Traditionally, the interest obtained by the provincial officials was inadequate. In order to get enough money to lead a comfortable life, they had to seek more interest by other means than plowing, gardening and trading. The provincial officials had the administrative power accorded by their positions and used it to get traditional services from the people. Therefore, when they worked for a living, they took advantage of their official positions to get profits more conveniently than other people. For example, when they 'plowed the land' ('tamna'), they relied on 'traditional sharing labour' ('bok kaek') from the people, or when they started businesses or went into businesses partnerships with anybody, they might offer more benefits or facilities to their partners. Even the tax-farmers who won the monopoly from Bangkok would be able to collect farm revenues more conveniently if the provincial officials had some share in the enterprise. Subsequently, the tradition of making a living through abuse of government positions emerged' (italics mine) (Damrong Rajanubhab, 2002:50).

Under the context of the 'farming system', the economy of Songkhla was under the influence of the Na Songkhla family i.e. tax and revenue collection both inside the town proper, around the outside areas and from the provinces under Songkhla's authority, bird-nest revenue collection, trade, and tin-mining. Since the $\mathrm{Na}$ Songkhla family could not undertake these economic activities all alone, the cooperation of the Chinese traders as the apparatus in mobilizing the local economic forces at different levels was necessary i.e. from the grass-roots community up to the town levels, internally and externally, including the junk trade with China and nearby provinces. Acting as the governing apparatus of the central power, the Na Songkhla family would appoint the Chinese traders to the position of 'provincial officials' called 'Chinese officials' ('Kromkarn Jeen'). For example, Chao Praya Wichiankiree (Tienseng Na Songkhla) appointed Kong Poy to be Luang Srisombat and Jeen Seng to be Luang Subhamatra (Prachum Phongsawadan, 
vol. 30 , p. 236) whereas Chao Phraya Wichiankiree (Boonsung $\mathrm{Na}$ Songkhla) appointed Jeen Kimsui to be Luang Bamrung-arkorn, Jeen Yok Seng to be Khun Pakdibaworn, and Chao Phraya Wichiankiree (Chom $\mathrm{Na}$ Songkhla) appointed several Chinese traders in Songkhla to be town officials e.g. Jeen Boonseng Sae Jiah to be Luang Trakpakdi, head of the Chinese in the Songkhla market, Jeen Wanchay to be Luang Photchana Sarabhan, and Boklong Laekagul to be Luang Bawornwathee, the central Chinese district official. The relatives of wealthy local Chinese merchants were also appointed to the position of provincial officials. ${ }^{5}$ For example, the brothers of Jeen Chunhawd were appointed to be Luang Nikornjeenphibhan, ${ }^{6}$ and Jeen Suitong Hiranworachart to be Luang Sukkasemsamothai, an assistant to the governor, a Chinese district official and a revenue collector (Biography and Ideology of Sanan Hiranworachat, 1998: $1)$.

Between 1775-1855, junk trade, which significantly constituted the external trade of Songkhla with China under the tributary system, was in the hands of the $\mathrm{Na}$ Songkhla family who acted as the sole local representative of the central power in sending goods to the Chinese market (Chotmaihet Reign 2 Chulasakaraj 1173, 1998: 21-22). It is highly likely that the

\footnotetext{
${ }^{5}$ National Archive, R 5 RL-GH/63 Jeen

Boonseng, titled Luang Trakpakdi, Indebted to Jeen Kangsui.

${ }^{6}$ National Archive, R 5 M 47/14 On the Interest and the Administration of Songkhla, Phatthalung and Nakhon (16 April-20 October RS 115).
}

Chinese traders participated in each of the $\mathrm{Na}$ Songkhla trade missions to China since several ships in an expedition would guarantee a safe trip in terms of mutual help and defense against piracy.

From 1842 onwards, however, trade along the tributary system gradually declined as China was forced by the Treaty of Nanking to open four free port cities i.e. Amoy, Ningpo, Shanghai and Fucho. In addition, technological advances in western navigation i.e. from junks to steamships, had made the journey faster and enabled ships to carry cargo in larger quantities. Such changes gradually decreased the role and importance of the junk trade and increased those of Penang and Singapore as centers of trade in Southeast Asia, the port cities collecting goods from hinterland Southeast Asia, India and Europe and disseminating those from China and Southeast Asia to India and Europe. The prominence of Singapore as the center of trade was emphasized when the Suez Canal route was opened in 1869 (Bogaars, 1955).

Changes in the economic context of Southeast Asia towards free trade (laissez-faire) via Penang and Singapore resulted in the Chinese traders in Songkhla being gradually less dependent on the power of the Na Songkhla family in their external trading activities. Now they could trade with Penang and Singapore without having to rely on the political power of the Na Songkhla family in their pursuit of economic interests through the tributary system previously based on China.

Subsequently, after 1896 the Na Songkhla family's role in the political, governing and economic realms, gradually decreased, and the Chinese traders came to play the leading role in 
the economic activities of Songkhla.

\section{Economic Activities of the Chinese traders, 1824-1912}

Trade was the prominent economic activity of Songkhla ever since its foundation due primarily to its suitable location as a port: a refuge from the monsoon and the gateway between Songkhla Lake and the sea (Gulf of Thailand). Significantly, Songkhla possessed several other assets: its hinterland was rich in natural resources along the Songkhla Lake, the U-Taphaw canal and in several provinces under its supervision. These assets attracted outside traders interested in trading with her. Internal and external trade intertwined in making Songkhla a port city and a center for the collection and dissemination of goods from the areas within the town proper to those outside.

\section{Internal Trade}

There were two types of internal trade:

1.1 Trade in the Songkhla Lake Basin and the U-Taphaw Canal. Middle-man traders collected goods from the villages and sold them to merchants in Songkhla, while at the same time they bought merchandise from Songkhla and sold it to the villagers. The traders comprised both Chinese natives and Chinese immigrants in Songkhla. This type of transaction in the lake basin and the U-Taphaw canal must have been an old practice as evident in the case of Jeen Yiang Sae How, the founder of the Na Songkhla family. After having accumulated funds from orchards for many years, he turned to trade at Laem Son and married two Phatthalung women (Prachum Phongsawadan, vol. 3, p. 36) of Chinese descent, one from the Lau family and another from the Chueng family (In Memory of the Cremation of Chao Phraya Strithammathibet, 1976: 404, 406). This exemplified the trading network built between the Na Songkhla family and other families in Phatthalung through marriage and kinship, a pattern that was passed on for many generations.

For trading navigation in the Lake, sailboats and junks were used to visit villages and communities where 'weekly markets' were held at various intervals. Traders could then rotate the selling and buying of merchandise from one village to another throughout seven days. ${ }^{7}$ The vessels used were called 'weekly market vessels' ('Rua Kha Nut'). ${ }^{8}$ Traders would import goods to sell in one village while at the same time, they bought local produce from the village to be sold in others. Thus while traders enhanced internal trade within the lake basin, they also disseminated goods from outside into the interior areas. For example, wild honey, and palm sugar from Ban Than Pho would be exchanged for rice and seasonal fruits with Phatthalung and Ranote. From Ban Tha-Pho to Phatthalung, Ranote and Songkhla proper, native traders would navigate along the internal trade routes of the lake basin using indigenous knowledge of the weather and water currents in the lake during each season. ${ }^{9}$ and the seasonal availability of agricultural or forest products in

\footnotetext{
${ }^{7}$ Interview, Mrs Phuanglek Wongsakul, age 80, 5-7

August 2002, and 8, 29 July 2003.

${ }^{8}$ Interview, Mrs Thanit Kulprayoth, age 78, 5 November 2003.

${ }^{9}$ Interview, Mr Charoensri Charoonsri, age 85, 16 October 2003.
} 
different communities. These native traders also visited Songkhla proper to buy cloth and salt to sell to the communities along the lake. ${ }^{10}$ Thus, they disseminated merchandise from Songkhla proper into the interior areas.

Native traders did not operate alone in the internal trade within the Songkhla lake basin, Chinese traders from Songkhla proper also participated in these trade ventures. They would visit weekly markets and import consumer and luxury goods such as gold ornaments. ${ }^{11}$ Trade went on for whole seven days before they sailed back to Songkhla carrying local products to be sold to the townspeople. Their weekly market vessels were docked along the piers behind their houses along Nakhon Noak road.

This type of trade within the Songkhla lake basin persisted for generations before it faded away after World War II. It is highly likely that such practices came into existence from the foundation of Songkhla at Hua Khaw Dang as evidenced by its three suitable sites at the mouth of the lake estuary, making it an entrepot as well as a major port city, as seen in voyage memoirs and accounts of foreigners who came to trade with Songkhla.

As for trade along the U-Taphaw canal, there was an ancient route linking trade between Songkhla and Kedah which passed through communities from the

\footnotetext{
${ }^{10}$ Interview, Mr Nophadol Anekachai, age 54, 8 July 2002.

${ }^{11}$ Interview, Mrs Phutsadee Charoenphong, age 81,5 July 2002.
}

mouth of U-Taphaw, Tha Haadyai, Ban Thako, Ban Khong-sra, Ban Bang Lau, Ban Thung Yaw, and Ban Thung Mo up to Ban Khaw Rupe Chang along the upper reaches of the UTaphaw canal. Then the route crossed some hills before it reached the Perlis River which flowed into the Andaman Sea where Langkawi Island is situated at its estuary. After a short trip along the seashore the route finally reached Kedah. ${ }^{12}$ This trade route was in use up to contemporary times.

Traders from various places would come to buy and sell at the weekly markets of the communities along the U-Taphaw canal. They imported goods from Songkhla such as dried shrimp, shrimp-paste, pots, jars, salt, and rice in exchange for local produce such as coconuts, betel-nuts, sugar-cane and all kinds of rattan to be sold at Songkhla, Penang and Singapore. There were also petty-traders from outside who constantly visited the communities along the canal not only for the weekly, markets. Buffalohorn trumpets would be blown as a sign of the cargo-vessels' arrival so that the villagers would bring their goods to exchange. The cargo-vessels would stop for one night before leaving for business in other communities. ${ }^{13}$

These descriptions show the movement of transactions in collecting and exchanging local products around the Songkhla lake basin and the U-Taphaw canal. Both native and Chinese traders acted as middlemen in the trade connecting the hinterland to Songkhla proper.

\footnotetext{
${ }^{12}$ Manit Walliphodom, 'KampochNakhon AyodhyaTambralinga', published on the occasion of the cremation of Somkiat Vessakosol under the auspices of His Majesty the King, February 1985), p. 119, quoted in Sukonthaphirom Na Phatthalung, p. 76.

${ }^{13}$ Interview, Mr Phichai Srisai, age 56, 26 November 2004.
} 
1.2 Trade within Songkhla Proper. There was another branch of trade whereby Songkhla was the center of goods from the hinterland and outer areas operated by the Chinese who came from various provinces and foreign lands i.e. China, Penang, and Singapore as well as the western people. Chinese traders opened wooden shops, grocery stores and brick buildings which were also used as their residences in the commercial quarters of the town (at the present time they comprise the areas around Nakhon Noak road, Nakhon Nai road and Kao-Hong Nang-ngam road). These shops sold mostly clothes and silk fabric (Prachum Phongsawadan, vol. 30 , p. 288). Among those locally produced were Pha Muang, ${ }^{14}$ Pha Pheen, ${ }^{15}$ Thai sarongs, silk and cotton sarongs, cotton and silk handkerchiefs, silk and cotton scarfs. Imported goods such as Pha Muang, silk and cotton Thai sarongs, silk and cotton napkins, and silk fabrics came from other provinces such as Bangkok and the Malay states (Phanuphanwongworadej, 1961: 71-75). The grocery stores sold miscellaneous goods sell as dishes, forks and spoons, spades and agricultural utensils, as required by the Chinese traders who would in turn sell them in the weekly markets in the communities around the lake basin. Agricultural produce was not in demand in the communities as they

\footnotetext{
${ }^{14} \mathrm{Pha}$ Muang is traditional Thai loin cloth twisted at the end and tied to the waist, specifically for high-ranking officials.

${ }^{15} \mathrm{Pha}$ Pheen is Thai loin cloth for ordinary Thai men.
}

used barter trade among themselves. ${ }^{16}$

Within Songkhla proper, the business quarter was quite active, with a dense population as evident since the time of Chao Phraya Wichiankiree (Boonsung) when King Rama IV visited Songkhla in 1859. 'The western and eastern provinces of the upper South and this town are lively. People are prosperous and the towns were dense [with] buildings, shops and markets [...] [All] enjoy trade [...]' (Prachum Phongsawadan, vol. 30 , pp. $275,278,287$ ). During the reign of King Rama V, in 1884, when Prince Phanuphanwongworadej visited Songkhla, these conditions were still apparent (Phanuphanwongworadej, 1961: 73). During his visit to the Malay Peninsula in 1891, King Rama V bought merchandise worth 80 dollars 3 sluengs from 118 shops and from the fresh stores outside the town walls (Rama V, 1964: 222) This shows that Songkhla had all kinds of merchandise from which to choose, especially woven cloth (Rama V, 1963: 13) which was a famous product. Earlier, when King Rama IV visited Songkhla in 1859, he bought several pieces of woven cloth (Prachum Phongsawadan, vol. 30, p. 288).

Trade prospered within Songkhla proper as evident in the number of shops which increased to 696 in 1898 . The revenue tax from trading businesses within Songkhla proper that year was 615,062 baht. ${ }^{17}$ Records indicate that products from communities within the lake basin and the U-Taphaw canal exceeded palm-sugar, coconut oil, poultry, shellfish,

\footnotetext{
${ }^{16}$ Interview, Mrs Phutsadee Charoenphong, age 81, 5 July 2002, and Mr Nophadol Anekachai, age 58, 8 July 2002.

${ }^{17}$ National Archive, R5 M 47/19, Report on Monthon Nakhon Si Thammarat (10 April 113 - 5 October 129).
} 
unhusked rice $(1,500$ kwiens, 1 kwien equivalents to 2000 litres) and rice (1,530 kwiens) from Phatthalung. As for export goods produced in Songkhla itself, pottery was prominent, with revenues of 6,183 baht, whereas unhusked rice, rice and live pigs were among those exports to other provinces and abroad, earning the revenues of 175,400 bath.

It can be concluded that Songkhla proper served both as a center for the collection of local products from the hinterlands, the lake basin, and the U-Taphaw canal, as a source of production of export goods, and as a center of foreign trade and transactions between internal and external markets. This condition persisted up to 1937, when its active role gradually declined. Nevertheless, the contemporary Chinese buildings and houses on both sides of Nakhon Nai and Nakhon Noak roads testify to the once lively past of Songkhla trade. ${ }^{18}$

\section{External Trade with Other Provinces along the Gulf Coast}

This branch of trade was carried on between Songkhla and other provinces: those under Songkhla supervision i.e. the seven Malay states, Kelantan and Trengganu, Phatthalung, Ban Don, and Chumphorn up to Bangkok. The traders involved in this branch of trade were those from the $\mathrm{Na}$ Songkhla family, provincial administrators and Chinese traders. These traders also worked as middlemen for foreign traders. The goods comprised those bought from the people

\footnotetext{
${ }^{18}$ Interview, Mrs Phuanglek Wongsukhon, age 80, 5-7 August 2002 and 8-29 July 2003.
}

(i.e. rice), collected from the lake basin, locally produced within Songkhla proper (i.e. earthen tiles, bricks, jars) and received as vested interests of Songkhla from the provinces under its supervision.

The general practice was as follows. The Chinese traders within Songkhla proper would use sailing boats to trade with provinces along the gulf coast from Bandon to Trengganu. Their counterparts in other provinces were mostly acquaintances or relatives. The business relationship between both sides eventually developed into trading networks such as those between Songkhla and Trengganu, Songkhla and Kelantan, and Songkhla and Penang. The Songkhla traders had their relatives work as trading agents who would arrange for the provision and disposal of required goods. In the case of external trade between Songkhla and Trengganu, shrimp-paste from Yor island (good quality for Nam-phik) and earthen tiles from Yor island and Songkhla proper would be exchanged for shrimp-paste (for curry) and brass from Trengganu. Imported goods would be sold in Songkhla and other coastal provinces such as Bandon. ${ }^{19}$ As for trade between Songkhla and Kelantan, shrimp-paste would be imported from Kelantan and bricks were exported from Songkhla. Seasonal fresh fruits were imported from Penang while dried seafood was exported back. Payments and investments were based on mutual trust between the buyers and sellers. The owners of the vessels who were buyers would take the merchandise from the producers on credit and the balance would be paid after the former sold the merchandise.

Significantly, external trade between Songkhla

\footnotetext{
${ }^{19}$ Interview, Mrs Iamjit Wijarn, age 69, 1 June 2002.
} 
and other provinces also led to the migration to and from both sides i.e. Songkhla traders went to undertake business in Nakon Si Thammarat, ${ }^{20}$ and Surathani traders moved to Songkhla and gradually became leading wealthy families (e.g. Choo family, Chooratharasan family, Ratarasan family and Prathanrasnikorn family (In Memory of the Cremation of Mr Nikorn Prathanrasnikorn under the Auspices of His Majesty the King, p. 71) or the Ngaorangsi family with its business lineage in Kelantan and Penang). ${ }^{21}$

\section{Trade with Singapore}

After Singapore was developed by the British and became the center of trade in Southeast Asia, trade between Bangkok and Singapore expanded enormously. Evidence shows that between July and December 1869, there were 52 vessels with Siamese flags trading in Singapore. ${ }^{22}$ During the same period, traders from Singapore visited the port cities in Southern Siam and also invested in business ventures in some of the provinces e.g. Pattani, ${ }^{23}$ Kelantan, and Songkhla. ${ }^{24}$ As a matter of fact, Songkhla

\footnotetext{
${ }^{20}$ National Archive, R5 RL-KH/9, Chao

Phraya Akramahasena's Order to Chao Phraya

Songkhla on Jeen Seng's Petition against Chao

Phraya Songkhla.

${ }^{21}$ Interview, Mrs Jirawan Ngaorangsri, age 82, 8 July 2003.

${ }^{22}$ National Archive, KT(L) 15, Vol 4, Revenue Lists on Ships at Singapore, AD 1869.

${ }^{23}$ National Archive, M R5 RL-KH/13, pp. 14449, Am Dang Tong's, Jeen Hongki's Wife, Appeal to Bangkok.

${ }^{24}$ National Archive, M R4 RL-KH/15, pp. 282 88; $\mathrm{KH} / 21$, pp. $158-67$; and $\mathrm{KH} / 5$, pp. 145-61.
}

was recorded as one of the port cities Chinese, Malay and foreign traders constantly visited. ${ }^{25}$ The volume of foreign trade undertaken by the Songkhla Chinese traders at the time greatly increased as observed in Phraya Sukumnaiwinit's (Pan Sukhum) Report on the Inspection of Nakon Si Thammarat in 1899. In 1897 , there were 720 ships trading between Songkhla and foreign cities at one time, while the number of ships in 1898 increased by $348 .^{26}$ The ships which were used to trade with Songkhla were not big, around 3-6 wa (Phanuphanwongworadej, 1961: 76) as the bigger ones would not be able to get into the lake channel. The great number of 720 ships trading with Songkhla probably also included Malay vessels which navigated along the Malayan coasts and stopped over at Songkhla to buy goods, especially rice (Narisaranuwatiwong, p. 55).

On the other hand, the Chinese traders from Songkhla also went to trade with Singapore, ${ }^{27}$ carrying goods from Songkhla to sell in Singapore and on their return carrying goods from Singapore to sell in Songkhla. ${ }^{28}$ The opportunities for trade between Songkhla and Singapore greatly increased when the contract for mail ships in the Southern provinces with venue from Bangkok to Singapore was signed between the Siamese government and the East

\footnotetext{
${ }^{25}$ National Archive, M R5 RL-KH/10, p. 255.

${ }^{26}$ National Archive, R5 M47/19, Report on Monthon Nakhon Si Thammarat (19 April 113 - 5 October 115).

${ }^{27}$ National Archive, R5 M2. 12K/1 (36), Official Letter from Songkhla Regarding Songkhla's Customers Buying Bullets from Singapore.

${ }^{28}$ Interview, Rat Prathanrasnikorn, age 83, 12

December 2001, and Six Cycles of Dr Rat

Prathanrasnikorn, 1992: 22.
} 
Asiatic Co. in $1899,{ }^{29}$ and renewed in 1904. The operation of the mail ships with fixed schedule greatly affected the movement of the economy of the Southern provinces. As Phraya Sukhumnaiwinit noted, agriculture and commerce in the Southern provinces was prospering and much would go on ${ }^{30}$ because the post mail-ships could transport cargo from several cities at the same time. The new contract of the East Asiatic Co. stated that the sailing schedule of the ships would be fixed and the ships would stop to send mails at the five cities which had a great volume of cargo. One of these cities was Songkhla.

Aside from the post-mail ships of the East Asiatic Co. which provided transport of cargo from Songkhla to other provinces and Singapore, there were two steamships i.e. Kaladit and Phatthana which belonged to Luang Udompakdi, ${ }^{31}$ one steamship from Singapore which sailed three times a month, including two ships from Bangkok i.e. Sukswadi and Sherd. ${ }^{32}$ The opening of steamship lines between Songkhla and Singapore enhanced transportation in the region as steamships could sail up to 15 16 times a year as compared to 3-4 times

\footnotetext{
${ }^{29}$ National Archive, R5 B 12/6, Post Shipping Contract between Bangkok and the South (2 April 122 - 10 July 148).

${ }^{30}$ National Archive, R5 B 12/6, Post Shipping Contract between Bangkok and the South (2 April 122 - 10 July 148).

${ }^{31}$ National Archive, R5 KH 14.2K/50, BirdNest Revenues (7 August - 24 June 128).

${ }^{32}$ National Archive, R5 M47/19, Report on Monthon Nakhon Si Thammarat (10 June 113 -5 October 129).
}

a year for junks. ${ }^{33}$ Moreover, junks were expensive from Kanchanadit or Chumporn, costing 1,000-2,000 baht. In 1882 the Chinese traders in Songkhla owned only 15 of the junks that traded with Singapore. ${ }^{34}$ The prominent families which had junk trade with Singapore were the Prathanrasnikorn family, the Sin Adulyaphan family, and the Siriwong family. ${ }^{35}$ Steamships only gradually replaced the junks as a means of transportation and trade between Singapore and Songkhla.

Exports from Songkhla to Singapore and the Malay States of Kelantan and Trengganu comprised traditional products collected from the hinterlands (bird-nest, rice, dried shrimp, salt, forest produces, and live pigs). There were also export products from Songkhla proper and the area nearby including Trengganu oranges, varieties of pottery such as earthen tiles, bricks, earthen crocks, large water jars and bowls.

\section{Trade with Penang}

Trade between Songkhla and Penang was possible through a land route -- Kedah road which was little more than two metres wide, built in $1907 .^{36}$ Kedah and Songkhla had the

\footnotetext{
${ }^{33}$ National Archive, R5 M47/19, Report on Monthon Nakhon Si Thammarat (10 June 113 - 5 October 129).

${ }^{34}$ National Archive, R5 M2.12 K/1 (108-114), Official Letter from Songkhla Regarding the Items Sent to Participate in Bangkok's Centennial Anniversary Exhibition.

${ }^{35}$ Interview, Rat Prathanrasnikorn, age 83, 12

December 2001, and Six Cycles of Dr Rat

Prathanrasnikorn, 1992: 22. Interviews, Mrs Prayul, age 83,16 June and 10 October 2003; Mrs

Chonnaphorn Preechaphanit, age 66, 3 July 2003; Ms

Sopha Siriwong, age 69, 3 May and 29 May 2005.

${ }^{36}$ National Archive, R5 M2.14/22, Phraya Sarit's

Report on the Inspection of Monthon Nakhon $\mathrm{Si}$
} 
road constructed from each side. It met at the borderpoint called Hua Thanon where a demarcation stone made from a rectangular slab of granite was set up ${ }^{37}$ (see map 1) (Sadao Heritage, 1990: 5). In fact the road was an elevated cart - walk, and was impassable during the rainy season as there were no bridges at several places where waterways cut across the road. It was not until 1907 when 69 bridges were built at Namkrajay, Namnoi, Klonghae, Haadyai, Banphru, Phratong, Phangla and Prik ${ }^{38}$ that trade between the two towns became much more convenient.

In trading with Penang, the Chinese traders from Songkhla went in groups of acquaintances in order to help each other during the journey as the road passed through woods where there were dangers from wild animals and bandits. Elephants and carts were used for the transportation of the goods. Traders would stop at communities along the way to buy local products. ${ }^{39}$ Livestock (buffaloes, goats, sheep, ducks and chickens) was very important nerchandise on the Kedah route. The animals were collected from the hinterlands where every district in Nakon Si Thammarat would hold weekly livestock markets at least twice a week, and an officer would be ready to issue

Thammarat (RS 113).

${ }^{37}$ At present, it is near the rice field, Mou 4, Ban Hua Thanon, Tambon Prik, Sadao District, Songkhla Province.

${ }^{38}$ National Archive, R5 M24.1/19, The Bridges in Monthon Nakhon Si Thammarat (2 April $120-29$ July 129$)$.

${ }^{39}$ Interview, Mrs Chonnaphorn Preechaphanit, age 66, 3 July 2003. identification stamps for the animals. ${ }^{40}$ The animals would then be brought to Hua Khaw Dang, and made to swim across to Songkhla at Bor Yang before proceeding along Kedah road. Initially, there were five check points on the way within the Songkhla border which made the journey costly and time-consuming. In 1897, four of the five check points were eliminated leaving only one in place. ${ }^{41}$ Before 1910 , the number of animals transported to Kedah through Songkhla was $6,000-7,000$. In 1910, an epidemic reduced the number to $2,000-3,000$, but this rose to 4,000 in 1896 . It was estimated that the number might have risen to $6,000-8,000$ in $1897 .^{42}$

Besides livestock, other merchandise exported to Penang included shrimp-paste, rice, salt, dried fish and Trengganu oranges. Penang merchandise imported to Songkhla comprised mainly consumer goods such as cloth, cotton thread, silk thread, shoes, dried fruits and Chinese products. Later, there were machines, bicycles, motor-cycles and cars from China and Europe. ${ }^{43}$

Communication between Penang and Songkhla was common as the traders of the two cities were often relatives or acquaintances. The

\footnotetext{
${ }^{40}$ National Archive, R5 M47/19, Report on Monthon Nakhon Si Thammarat (10 July 113 - 5 October 129).

${ }^{41}$ National Archive, R5 M99/51, On the Abolition of Cock-Fighting Gamble and Custom Posts in Songkhla.

${ }^{42}$ National Archive, R5 M47/14, On the Interest and Administration in Songkhla, Phatthalung, and Nakhon (15 April - 20 October 115).

${ }^{43}$ Interviews, Mr Pin Phongphrayul, age 85, 10 October 2003, Mr Sutha Ratanaphuek, age 77, 16 October 2003, Mrs Jureerat Niphatsat, age 72, 13 October 2003, Mrs Iamjit Wijarn, age 69, 1 June 2002, Mr Nophadol Anekachai, age 53, 8 July 2002.
} 
relationship between the two partners was close enough for the Songkhla entrepreneurs to send their children to study in Penang and stay with their counterparts in order to learn Chinese, Malay and English which would be beneficial for their future business. Sending their children to study in Penang under the care of and/or staying with their relatives or trustworthy partners was a popular practice anoag the Chinese traders in Songkhla. ${ }^{44}$ On the other hand, the Penang entrepreneurs would come to settle and invest in Songkhla, and undertake business in partnership with their relatives in Penang. ${ }^{45}$

\section{Other Economic Activities}

Rice Milling. Rice milling was another major economic activity of the Chinese traders in Songkhla. It was an investment in relation to the hinterlands around the Songkhla lake basin, which had long been an important rice growing area. Songkhla was the center of rice collection to be exported to other provinces. The first rice mill was set up in Songkhla by a member of the $\mathrm{Na}$ Songkhla family, Luang Udompakdi (Phan Na Songkhla), some time not before 1905 when the first ricemill at Pak-Phanang was opened. After his death in 1919, it was sold to a Nakon $\mathrm{Si}$ Thammarat businessman. It later fell into the hands of Chinese Singaporean entrepreneurs. The business stopped after

\footnotetext{
${ }^{44}$ National Archive, R5 M47/14, On the Interest and Administration in Songkhla, Phatthalung, and Nakhon (15 April - 20 October 115).

${ }^{45}$ Interview, Mrs La-or Suwanayuha, age 72, 5 August 2004.
}

World War II (Ungwithayathorn, 2001: 80-81) when there was not enough rice and a great number of small rice-mills were opened along the lake basin.

There was another rice-mill belonging to Khun Rachakitkaree (the Saowaphuek family), a town official in partnership with his relatives, Khun Phokhaphipat (Khow Huadliand) and the Konan family. ${ }^{46}$ It was set up in $1911 .{ }^{47}$ Initially the operation of the rice-mill used petroleum engines. Later after it fell solely into the hands of Suchart Rattanaprakarn, his grandson, steam engines directly ordered from England were used instead. The supply of rice for the mill was carried by rice-boats (Lamjune) from Ranote, Huasai and Phatthalung whereas some was collected from villagers by the middlemen who sailed along the lake. The rice-milling business went on until after World War II. ${ }^{48}$

Other rice-mills were opened between 19271937. For example, Sun-Huad Siang Rice-Mill at Saphan Lek ('the Iron Bridge'), which was called 'Iron Bridge Mill', belonged to Pai Ja. There were also Khun Jinda Mill (Hok Seng Hin Mill) whose owner inherited it from his father, Chaijin, who was given the title of 'Khun', as well as Khun Teub's rice-mill which was situated at Thesa Bridge, ${ }^{49}$ Nakhon Phanit Mill and Wat Shynam Mill (Ungwithayathorn, 2001: 82-83).

\footnotetext{
${ }^{46}$ Interview, Mrs Manee Na Songkhla, age 80, 9

March 2005.

${ }^{47}$ Interview, Mrs Manee Na Songkhla, age 80, 9

March 2005.

${ }^{48}$ Interview, Ms Nobhanapha, age 72, 28 May and 8

October 2003.

${ }^{49}$ Interview, Mr Thanit Kulaphrayote, age 78, 5

November 2003.
} 
Pottery and Brick Production. The production of pottery and brick was another economic activity, the technology of which came from China. Its production as an industry began in the time of Chao Phraya Wichiankiree (Boonsung). Actually, Songkhla was a major source of good quality clay. Ban Bor Phab and Yor Island both became production sites of large pottery water jars, bowls, earthenware, and pottery called 'Songkhla brick' and 'Songkhla tiles' which were famous products of Songkhla. On the northern side of Yor island, there were three pottery factories (Phanuphanwongworadej, 1961: 68) whereas at tambon Bor Phab around the place called 'Toa It' ('Kiln'), outside the town walls on the Southern side, a mold factory produced very fine, thin tiles as there existed good quality clay (Phanuphanwongworadej, 1961: 64-65). Besides, there were other pottery resources with no less than 200 kilns along the southern lakeside from Tha It Thasa-Aan, Tha Nang-Hoam, Wat KhokPuea to Ban Bang-Note (Inthongkhong, 'Songkhla's Pottery', in In Memory of Suchart Rattanaprakarn, 1983) These tiles and pottery were exported to other provinces such as Pattani and Kelantan. Songkhla's pottery and tile industry continued until sometime before World War II. $^{50}$

\section{Trengganu Orange Orchards} ('Somjuk'). Trengganu oranges were a famous agricultural export from Songkhla. Big plantations of Trengganu

\footnotetext{
${ }^{50}$ Interview, Mrs Iamjit Wijarn, age 69, 1 July 2002.
}

oranges were operated by the Chinese around the U-Taphaw estuary. There were about 20 orange orchards on both sides of the U-Taphaw canal (Phanuphanwongworadej, 1961: 65). The produce was exported to many provinces, especially Kedah.

Fishery. Fishery was a common profession among the Chinese and Muslims. The fishing resource of the Muslims was in the lake, whereas that of the Chinese was in the Gulf In actual fact, most of the Muslims from Ban Bon, the area around Bor Phab, including those at Laem Son and Hua Khaw Dang, were fishermen as the areas from Hua Khaw Keaw to Yor island were plentiful sources of a large variety of fish. All kinds of traditional fishing equipment was utilized in the fishing activities e.g. phong-phang, yok-yor, lobe, kat-thi, kathang, ${ }^{51}$ sum-krop-pai, ${ }^{52}$ sai and moh. $^{53}$

On the other hand, fishery in the outer sea or the Gulf of Thailand, was dominated by Chinese fishermen. The major fishing activity here was fishing stakes ('Poh') which required intensive capital investment, but the return was also very high as the money from the catch could last up to six months while one month's catch would cover the cost. ${ }^{54}$

In conclusion, various economic activities undertaken by the Chinese traders were

\footnotetext{
${ }^{51}$ National Archive, R5 M2.14/22, Phraya Sarit's Report on the Inspection of Nakhon Si Thammart (RS 113).

${ }^{52}$ National Archive, R5 M2.12K/1 (111), Official Letters from Songkhla Regarding Lists of Items Sent to Participate in Bangkok's Centennial Anniversary Exhibition.

${ }^{53}$ Interview, Mr Jaroen Jarulesri, age 84, 16 October 2003, and Mrs La-or Suwanayuha, age 72, 5 August 2004.

${ }^{54}$ Interview, Mrs La-or Suwanayuha, 5 August 2004.
} 
constantly expanded, both within Songkhla proper, in the lake basin and with outside provinces. They were operated both by land and by sea. The symbiotic movement of the internal and external economy contributed to Songkhla's growth as a port city and an entrepot where products were collected and then transported from the hinterlands to outside markets, and to Singapore and Penang.

\section{The Growth of Songkhla Proper, 1842-1912}

When the town was moved to Bor Yang, the physical character of Songkhla changed tremendously. The area on the western side of the town was the densely populated economic center. Many roads were built to connect the interior and outer areas of the town walls. For instance, the road from Khaw Noi to Machima temple passed the central market downtown (Prachum Phongsawadan, vol. 30, pp. 258-59), the road from Phayaknamruengdej gate passed through Chaiyut gate towards Samrong canal. There were two wells, three travelers' shelters (In Memory of Suchart Rattanaprakarn, 1983: 48) and a bridge across Kwang canal built when Chao Phraya Wichiankiree (Boonsung) was in power (Phongsawadan Muang Songkhla, 1939: 48). The construction of this road made communication between Songkhla town and peripheral communities like Tungwang and Khaw Rupechang much more convenient and helped expand the internal trade of Songkhla (Prachum Phongsawadan, vol. 30 , pp. 275, 278, 287).
The dynamism of economic activities undertaken by the Sino-Thai traders enhanced the growth of Songkhla, especially in the commercial center around Nakhon Nai and Nakhon Noak roads. In 1910, the inner space of the town was granted the status of 'Sukaphiban Tambon Talat' -- a lower local government. The Sukaphiban Tambon Talat covered 992 households, 2,217 houses and 6,568 people. ${ }^{55}$

The growth of Songkhla was also attributed to its being the command seat of Monthon Nakon $\mathrm{Si}$ Thammarat. This encouraged the expansion of the town proper to the north and east. Phrya Sukhumnaivinit (Pun Sukhum), the Thesaphiban governor, had many government buildings improved and built, including the town hall, the courthouse, the post office and many big roads for cars both within and outside the town. ${ }^{56}$

As there was a demand on the side of the government for the utilization of land in the future, therefore, the State Land Act of 1975 , article 4 and 11 (Songkhla's State Land, Summary of Land Issues According to Songkhla's District Office 1 November 115) was issued on the preservation of land in the northern and eastern sides of the town along the old wall. This became an obstruction to the growth of Songkhla as a major economic center in the future.

The population in Songkhla was a mixture of Thais, Chinese and Muslims. The Thais were the natives who lived in the area from the

\footnotetext{
${ }^{55}$ National Archive, R5 M12.2/7, On the Sukhlaphiban Tambon Talat, Muang Songkhla RS 128 (25-26 August 128).

${ }^{56}$ National Archive, R5 M2.14/47, The Minister of Interior's Inspection of the Southern Provinces (7 December 115).
} 
beginning, mostly around Laem Son and Bor Yang. However, some settled side by side with the Chinese and the Muslims. Some Thai groups were fishermen and petty traders whereas those at Yor island had orchards.

The Chinese were immigrants from China. For expediency in trade, they settled together in the commercial areas on both sides of Nakhon Noak and Nakhon Nai roads and along the coast on the eastern side of the lake. Their residences were row houses in Chinee architecture style. Some of the Chinese were fishermen, agriculturalists, and pottery and tile producers. There were pottery factories on the river bank about 40 meters to the south of the town wall, and at Bor Phlab which was famous for the production of pottery bricks, tiles, water jars, vases and spittoons. ${ }^{57}$ Nevertheless, the Chinese also scattered in other places such as Yor island and Sathingphra. As for the Muslims, most of them settled in groups around Bor Phlab or at Bon on the southern side of the commercial area of the Chinese. The majority of the Muslims were fishermen. Some were traders. The Laem Son area was densely populated by Muslims from the sub-districts south of the governor's house up to Khaw Kheo (Phanuphanwongworadej, 1961: 69).

The three ethnic groups were interdependent and came into contact with each other through trade activities in

\footnotetext{
${ }^{57}$ National Archive, R5 M2.12G1 (109-110), Official Letters from Songkhla Regarding Lists of Items Sent to Participate in Bangkok's Centennial Anniversary Exhibition.
}

which the Chinese were middlemen. Each group had its own expertise: the Thais were good at ploughing and gardening. The Chinese excelled in trade and the Muslims in fishing. Songkhla proper was the home of these ethnic groups. In 1884 , the population of Songkhla was 50,000: 40,000 Thais, 2,000 Chinese, and 10,000 Muslims (Phanuphanwongworadej, 1961: 70).

In additeoir within the walls there were religious buildings of various devotees: six Buddhist temples, five Chinese shrines and one mosque. The location of religious buildings clearly illustrates the pattern of ethnic residences within Songkhla proper.

\section{The Communities in the Central Commercial Area along Nakhon Nai and Nakhon Noak Roads}

The commercial center of Songkhla was located along the lake, on the eastern and western sides of the town wall on Nakhon Nai and Nakhon Noak roads. It covered the area both inside and outside the town wall as the wall was constructed after the communities had been established. There were a large number of residences on the Songkhla lake side as it was convenient to communicate with their relatives in the communities across the lake on the Laem Son peninsula. Residences on Nakhon Nai and Nakhon Noak roads were various. There were Thai thatch-roof houses or houses with tile roofs, Chinese tile roof houses and Chinese style buildings. It was estimated that within the town proper, one of three buildings were thatch-roof houses (Phanuphanwongworadej, 1961: 60-62).

The residences of the Chinese traders were also utilized as commercial buildings and shops. 
Traditionally, the Chinese row buildings, each normally 5 meters wide, and 20 meters long, were divided into three parts. The front part of the house was a half story building whose upper floor was used to store merchandise. ${ }^{58}$ The second part was a patio for domestic activities with a well in the middle. The third part usually with two stories was the sleeping place for the members of the family.

These shops sold a variety of merchandise. Those on Nakhon Nai Road sold mostly clothes and fabrics (Prachum Phongsawadan, vol. 30, p. 288) both locally produced and imported from other provinces (Bangkok and the Malay states) $)^{59}$ such as Pha Muang, loin cloths, white cloths, silk and cotton sarongs, scarfs, napkins and Chinese workers' blouses (Phanuphanwongworadej, 1961: 74-75). There were also many shops selling religious (Buddhist) accessories, such as monks' robes as there were many temples within the town and there was a great demand for these goods for religious offerings during Buddhist festivals. The shops on Nakhon Nok Road were mostly grocery stores, selling consumer goods and farming equipment. The merchandise came from local merchants or from Bangkok, Penang and Singapore. They were goods in demand and both the local Chinese merchants around the lake and within the town itself would disseminate them at weekly village markets. ${ }^{60}$

\footnotetext{
${ }^{58}$ Interview, Mrs Chonnaphorn Preechaphanit, age 66, 3 July 2003.

${ }^{59}$ Interview, Mr Sutha Ratanaphuek, age 77, 5, 16 September 2003, and Mrs Iamjit Sakharin, age 71, 7 August 2003.

${ }^{60}$ Interview, Mrs Phutsadee Charoenphong,
}
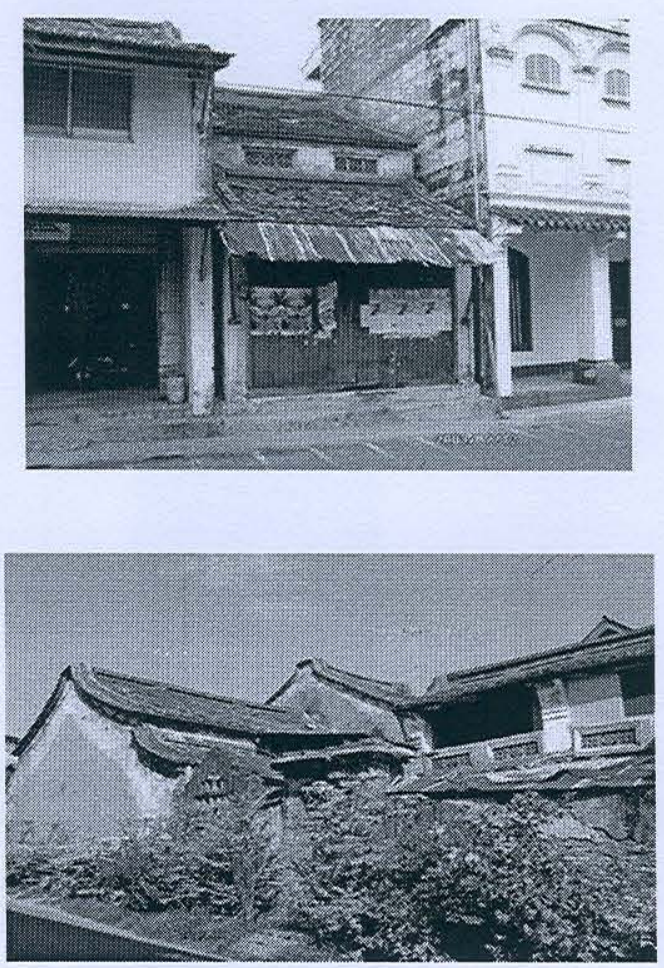

Besides this commercial center, there were two other markets for petty merchants of the three ethnic groups. One situated outside the wall, beside the lake, was originally called 'the Old Market' or 'Thalat Ban Bon'. Another, 'the New market', was situated near the wall on the northern side -- around Don Ruk temple. The latter was built in 1896 by the initiation of Phra Wijitworasan (Pun Sukhum), the then Thesaphiban governor of Monthon Nakon Si Thammarat in order to earn rent to fund the market and roads in downtown Songkhla. The buyers who frequently came to the two markets can be divided into two groups: 'Chow Bok' ('the Land people') who lived in the areas from

age 81, 5 July 2002, and Mr Nophadol Anekachai, age 58,8 July 2002 . 
Hua Khaw Dang to Sathingpra and Ranote, and 'Chao Nua' ('the Northern People') who lived around Tungwang, Namkrajay, Namnoi and Haadyai. There were also buyers from Pak-phanang. Trade within Songkhla proper was very lively during the 'Duen Sip' festival (10 ${ }^{\text {th }}$ lunar month to celebrate Wan Ching Phret, 'the day of the Ancestors') in October when people would come to shop and buy festival deserts. ${ }^{61}$

The relationship between the Chinese along Nakhon Nai and Nakhon Nok roads was closely-knit.They were relatives for generations and after 3-4 generations they inter-married, leading to alliances between various families, such as the Konan, the Rattanaprakarn, the Laekhagul, the Phrathanrasnikorn, the Ratarasan and the Na Songkhla.

\section{Conclusion}

Even though the role and importance of the $\mathrm{Na}$ Songkhla family gradually declined from 1896 onwards, the continuation of economic activities of Chinese traders in Songkhla between 1896-1912 enabled Songkhla to maintain its economic status as a port city as well as the strategic political and administration center of the lower South. During the period, Songkhla proper comprised the part which was the center of government offices on the northern and eastern sides of the town, aroand the Monthon Hall, post and telegraph offices,

\footnotetext{
${ }^{61}$ Interview, Ms Suda Charoenkonkit, age 71, 1 September 2003 and 8 October 2003.
}

the court house and others. The economic center was located in the middle of the town along the Nakhon Nai and Nakhon Noak roads, an area densely populated, with shops, buildings and row houses of the Chinese who were in close-knit relationships through intermarriage. The interactions between the Chinese and other major ethnic groups (the Thais and the Muslims) were interdependent through economic transactions. Actually as revealed in this article, trade and the Chinese traders between 1896-1912 played a key role in the development and dynamism of Songkhla as a port city.

\section{References}

\section{Primary Sources}

National Archive, KH/5, pp.145-161.

National Archive, KH/21, pp. 158-167;

National Archive, KT(L) 15, Vol 4, Revenue Lists on Ships at Singapore, AD. 1869.

National Archive, M R4 RL-KH/15, pp. 282-288 ;

National Archive, M R5 RL-KH/10, p. 255

National Archive, M R5 RL-KH/13, pp. 144-149, Am Dang Tong 's, Jeen Hongki's Wife, Appeal to Bangkok.

National archive, R5 B 12/6, Post-mail Shipping Contract Between Bangkok and the South (2 April 122-10 July 128).

National Archive, R5 Kh 14.2K/50, Bird-Nest Revenues (7 August - 24 June 128).

National Archive, R5 M2.12G1( 109-110), Official Letters from Songkhla Regarding Lists of Items Sent to Participate in Bangkok's Centennial Anniversary Exhibition.

National Archive, R5 M2.12K/1 (36), Official Letter from Songkhla Regarding Songkhla's Customers Buying Bullets from Singapore.

National Archive, R5 M2.12 K/1 (108-114), 
Official Letter from Songkhla

Regarding the Items Sent to

Participate in Bangkok's Centennial

Anniversary Exhibition.

National Archive, R5 M2.12K/1(111),

Official Letters from Songkhla

Regarding Lists of Items Sent to

Participate in Bangkok 's Centennial Anniversary Exhibition

National Archive, R5 M2.14/22, Phraya

Sarit 's Report on the Inspection of

Monthon Nakon Si Thammarat (RS. 113).

National Archive, R5 M2.14/47, The Minister of Interior's Inspection of the Southern Provinces (7 December 115).

National Archive, R5 M12.2/7, On the Sukhlaphiban Tambon Talat, Muang Songkhla RS. 128 (25-26 August 128).

National Archive, R5 M24.1/19, The Bridges in Monthon Nakon $\mathrm{Si}$ Thammarat (2 April RS. $120-29$ July 129).

National Archive, R5 M47/14, On the Interest and Administration in Songkhla,Phatthalung and Nakhon (15 April - 20 October 115).

National Archive, R5 M 47/19, Report on Monthon Nakon Si Thammarat (10 April 113 - 5 October 129).

National Archive, R5 M99/51, On the Abolition of Cock-fighting Gamble and Custom Posts in Songkhla.

National Archive, R5 RL-GH/63 Jeen Boonseng, titled Luang Trakpakdi, Indebted to Jeen Kangsui.

National Archive, R5 RL-KH/9, Chao Phraya Akramahasena 's Order to Chao Phraya Songkhla on Jeen Sang's Petition against Chao Phraya
Songkhla.

Books

Biography and Ideology of Sanan

Hiranworachart. 1998.

Bogaars, George. 1955. The Effect of the

Opening of the Suez Canal on Trade and Development of Singapore. Journal of the Malayan Branch of the Royal Asiatic Society 22.1:99143.

Chotmaihet Reign 2 Chulasakaraj 1173. 1998. Bangkok: Kurusapha.

Damrong Rajanubhab, Prince. 2002. Thesaphiban. Bangkok: Matichon.

In Memory of Suchart Rattanaprakarn. 1983. In Memory of the Cremation of Chao Phraya Srithammathibet (Jitre Na Songkhla) under the Auspices of His Majesty the King. 1976. Bangkok: Chuanpit.

Narisaranuwatiwong, Prince. 1997. Jotmai Rayathang Pai Truat Rachakarn Laem Malayu RS 121. Bangkok: The Fine Arts Department.

Phanuphanwongworadej, Prince. 1961. Cheweewat. Bangkok: Kurusapha.

Phongsiribanyat, Piang-kae. 1979. The Administration Policy of Songkhla during Bangkok Period. MA Dissertation, Department of History, Faculty of Arts, Chulalongkorn University.

Rama V, King. 1963. Phrarachahathalekha Reung Sadet Praphas Laem Malayu. Bangkok: Kurusapha.

Rama V, King. 1964. Rayathang Sadet Phrarachadamnuen Thang Bok Thang Rua Rob Laem Malayu RS 109. Bangkok: Kurusapha.

Sadao Heritage. 1990.

Six Cycles of Dr Rat Prathanrasnikorn. 1992. Bangkok: Amarin. 
Srithammathibet, Chao Phraya. 1939.

Phongsawadan Muang

Songkhla. Bangkok: Sor Karn Pim.

Sukhonthaphirom Na Phatthalung, Suphatra. History of the Family of Sultan Suleiman. In The Suleiman Lineage.

Wallipodom, Manit. 1985.

KampochNakhon AyodhyaTambralinga. Published on the occasion of the cremation of Somkiat Vessakosol under the auspices of His Majesty the King.

Wichiankiree, Phraya. 1963. Phongsawadan Muang Songkhla. In Prachum Phongsawadan. Vol. 3. Bangkok: Kurusapha.

Wichiankiree, Phraya. 1963.

Phongsawadan Muang Songkhla. In Prachum Phongsawadan. Vol. 30.

Bangkok: Kurusapha.

Ungwithayathorn, Chawalit. 2001. The Transaction and Rice Trade in the Songkhla Lake Basin.

Bangkok: Office of the Thailand Research Fund.

\section{Interviews}

Mr Charoensri Charoonsri, age 85, 16 October 2003.

Mrs Chonnaphorn Preechaphanit, age 66, 3 July 2003.

Mrs Iamjit Wijarn, age 69, 1 June 2002.

Mr Jaroen Jarulesri, age 84, 16 October 2003.

Mrs Jirawan Ngaorangsi, age 82, 8 July 2003.

Mrs Jureerat Niphatsat, age 72 June and 13
October 2003.

Mrs La-or Suwanayuha, age 72, 5 August 2004.

Mrs Manee Na Songkhla, age 80, 9 March 2005.

Mr Phichai Srisai, age 56, 26 November 2004.

Mrs Phuanglek Wongsukol, age 80, 5-7 August 2002 and 8, 29 July, 2003.

Mrs Phutsadee Chareonphong, age 81, 5 July 2002.

Mr Pin Phongphrayul, age 85, 10 October 2003.

Mrs Prayul, age 83, 16 June and 10 October 2003.

Mr Nophadol Anekachai, age 54, 8 July 2002.

Ms Rat Prathanrasnikorn, age 83, 12 December 2001.

Ms Sopha Siriwong, age 69, 3 May and 29 May 2005.

Ms Suda Chareonkonkit, age 71, 1 September,8 October 2003.

Mr Sutha Ratanaphuek, age 77, 16 October 2546.

Mrs Thanit Kulprayoth, age 78, 5 November 2003. 